\title{
PENERAPAN METODE TASK-BASED LEARNING UNTUK MENINGKATKAN KETERAMPILAN MENULIS SURAT BISNIS BAHASA INGGRIS
}

\author{
Rr. Conny Riana Dewi Murtiningrum ${ }^{1}$, Zainal Rafli ${ }^{2}$, Asti Purbaini ${ }^{3}$ \\ Pascasarjana Universitas Negeri Jakarta \\ ${ }^{1}$ connyrianadewi@gmail.com
}

\begin{abstract}
Abstrak
Tujuan penelitian ini untuk meningkatkan keterampilan menulis surat bisnis berbahasa Inggris pada siswa kelas XII AP1 SMK Pembangunan Jakarta melalui metode Task-Based Learning. Penelitian ini menggunakan desain penelitian tindakan kelas yang berlangsung dua siklus. Data dianalisis dengan menggunakan teknik analisis deskriptif kuantitatif dan kualitatif. Hasil penelitian menunjukkan bahwa (1) Kegiatan guru pada siklus I mendapat skor 24 dengan kategori baik dan meningkat pada siklus II dengan skor 31 dengan kategori sangat baik. (2) Aktivitas Siswa pada siklus I dengan persentase $52 \%$ meningkat pada siklus II menjadi $83 \%$. (3) Hasil belajar siswa pada siklus I mengalami ketuntasan klasikal sebesar $60 \%$ dan mengalami peningkatan pada siklus II menjadi 90\%. Kesimpulan penelitian ini menunjukkan bahwa penggunaan metode TaskBased Learning dapat meningkatkan keterampilan siswa dalam menulis surat bisnis berbahasa Inggris yang ditandai dengan meningkatnya kegiatan guru, aktivitas siswa, dan hasil belajar siswa.
\end{abstract}

Kata Kunci: Task-Based Learning, Menulis Surat Bisnis, Bahasa Inggris

\begin{abstract}
The purpose of this study was to improve the skills of writing English business letters for students of class XII AP1 of Jakarta Pembangunan Vocational School through the Task-Based Learning method. This study uses a classroom action research design that lasts two cycles. Data is analyzed using quantitative and qualitative descriptive analysis techniques. The results of the study show that (1) the teacher's activity in the first cycle gets a score of 24 with good categories and increases in the second cycle with a score of 31 with a very good category. (2) Student activities in the first cycle with a percentage of $52 \%$ increase in the second cycle to $83 \%$. (3) Student learning outcomes in the first cycle experienced classical completeness of 60\% and increased in cycle II to $90 \%$. The conclusion of this study shows that the implementation of the Task-Based Learning method can improve students' skills in writing English business letters which is characterized by increasing teacher activities, student activities, and student learning outcomes.
\end{abstract}

Keywords: Task-Based Learning, Writing Business Letters, English 


\section{PENDAHULUAN}

Tujuan pembelajaran bahasa adalah agar peserta didik mampu berkomunikasi baik secara lisan maupun tulisan. Dalam mengungkapkan dan memahami bahasa lisan dan tulisan, seseorang memerlukan keterampilan berbahasa yang baik. Seperti dikutip dalam Henry (2008:1) bahwa keterampilan berbahasa diperoleh melalui pembelajaran bahasa di mana terdapat empat keterampilan yang merupakan satu kesatuan. Dalam hal ini bahasa yang digunakan adalah bahasa Inggris.

Merujuk pada Pasal 37 ayat (1) dalam Undang-Undang Sistem Pendidikan Nasional No. 20 Tahun 2003 menyebutkan bahwa bahasa asing terutama bahasa Inggris merupakan bahasa internasional yang sangat penting kegunaannya dalam pergaulan global. Hal ini dipertegas oleh Ulfa (2018: 62) menyatakan bahwa dalam pembelajarannya, guru dituntut untuk melatih siswa menggunakan bahasa Inggris baik secara lisan maupun tertulis dan tidak semata-mata mengajarkan pengetahuan tentang bahasa itu sendiri. Begitu juga di dalam asesmen, guru sangat diharapkan menilai kemampuan siswa secara otentik dalam arti disesuaikan dengan dunia kerja, baik itu penggunaan bahasa secara lisan maupun tertulis. Salah satu keterampilan berkomunikasi yang harus kuasai adalah keterampilan berkomunikasi secara tertulis. Ada beberapa kompetensi dasar pada materi pembelajaran bahasa Inggris Sekolah Menengah Kejuruan (SMK) yang membahas mengenai komunikasi secara tertulis, salah satunya adalah kompetensi dasar menulis surat bisnis yang diajarkan pada kelas XII.

Keterampilan menulis adalah salah satu aspek keterampilan berbahasa yang dominan digunakan dalam kehidupan sehari-hari. Diperkuat dengan pendapat dari Istiara dan Lustyantie (2017:22) yang menyatakan menulis merupakan keterampilan yang paling sulit dikuasai oleh pembelajar L2 (bahasa kedua). Kesulitan ini tidak hanya dalam mengembangkan dan menyusun ide-ide tersebut ke dalam teks, tetapi juga menterjemahkan ide-ide tersebut ke dalam teks yang dapat dibaca. Dengan belajar menulis siswa akan lebih terampil dalam mengembangkan berbagai gagasan yang dimiliki ke dalam bentuk tulisan (Pujiastuti, 2016: 172), sedangkan keterampilan menulis dapat diartikan menuangkan buah pikiran ke dalam bahasa tulis melalui kalimat yang dirangkai secara utuh dan jelas sehingga dapat dikomunikasikan kepada pembaca dengan berhasil (Fitri, 2016: 119).

Kenyataan di lapangan terdapat kelemahan-kelemahan yang berkaitan erat dengan guru yang mengajar dan peserta didik yang belajar. Kelemahan tersebut antara lain: (1) model pembelajaran konvensional, di mana pembelajaran berpusat pada guru sehingga terlihat guru lebih mendominasi kelas dari pada peserta didik. (2) guru masih menggunakan metode ceramah dan belum menggunakan metode pembelajaran yang dapat membuat siswa tertarik dan berminat mengikuti pembelajaran; (3) rendahnya kemampuan siswa dalam menulis, beranggapan bahwa pembelajaran menulis itu pembelajaran yang sangat sulit; (4) kurangnya minat dan motivasi siswa untuk berlatih menulis; dan (5) siswa belum mengusai ejaan, kosakata dan tanda baca dengan tepat. Masalah ejaan, memang soal kecil menurut pikiran sebagian orang. Namun, dampaknya sangat penting bagi eksistensi suatu bahasa. Karena ejaan adalah infrastruktur sebuah bahasa agar menjadi acuan dalam menerapkan suatu bahasa dalam bentuk tertulis.

Salah satu cara mengukur keberhasilan pembelajaran adalah melalui tes keterampilan menulis surat bisnis bahasa Inggris di SMK Pembangunan yang dilihat dari pencapaian nilai Kriteria Ketuntasan Minimal (KKM) yaitu 75. Hasil tes yang dilakukan sebanyak dua kali pada peserta didik kelas XII AP-1 yang berjumlah 30 peserta didik 
hanya 7 orang siswa yang dinyatakan tuntas $(23,33 \%)$ dan sisanya sekitar 23 orang siswa yang dinyatakan tidak tuntas $(76,67 \%)$.

Data tersebut menunjukkan bahwa Keterampilan menulis surat bisnis dalam mata pelajaran bahasa Inggris di kelas XII AP-1 pada Kompetensi Dasar tentang salah satu bentuk surat bisnis yaitu surat lamaran kerja pada K.D 3.4, K.D. 4.4., 4.5., dan K.D. 4.6. dinyatakan belum tuntas. Ketidaktuntasan tersebut terlihat dari bukti presentasi ketuntasan seluruh siswa hanya mencapai 23,33\%. Persentase tersebut jauh dari persentase ideal $86 \%$ sampai $100 \%$. Bahkan persentase tersebut lebih kecil dari pada persentase ketidaktuntasan.

Untuk meningkatkan persentase ketuntasan atau keterampilan siswa dalam menulis surat bisnis berbahasa Inggris tentunya guru di tuntut memperbaiki pembelajaran dengan metode pembelajaran yang dapat mendorong minat serta memotivasi siswa agar keterampilan menulisnya dapat meningkat. Dan metode ini dapat memberikan kesempatan pada siswa untuk mengekspresikan ide mereka pada saat mempraktikkan dengan menggunakan bahasa yang dipelajari. Ada beberapa metode pembelajaran yang telah dikembangkan untuk meningkatkan keterampilan menulis surat bisnis berbahas Inggris salah satunya adalah metode task-based learning (Pembelajaran Berbasis Tugas).

Ali dkk. (2017: 114) mendefinisikan metode task-based learning adalah model pembelajaran yang termasuk dalam model peningkatan keterampilan menulis; model pembelajaran yang mencakup pemecahan masalah; secara garis besar mencakup tahap komunikatif; dapat mendorong atau mendukung motivasi siswa; dan memberikan keuntungan kepada siswa misalnya dengan memberi siswa kesempatan untuk mentransfer pengetahuan yang sudah pernah diperolehnya ke dalam konteks komunikatif. Tujuan menggunakan metode task-base learning agar siswa secara aktif mencari sendiri pengetahuan-pengetahuan yang belum mereka dapatkan sebelumnya. Dengan metode ini diharapkan siswa dapat berlatih mandiri dan percaya pada keterampilan mereka sendiri sehingga akan berdampak pada hasil pembelajaran yang berkualitas tinggi (Artamiati, 2017:97). Nurjanna (2015: 138) berpendapat berdasarkan karakteristik yang ada pada metode Task-Based Learning, di mana guru memberikan tugas dalam menulis surat yang dapat siswa lakukan di sekolah dan di rumah agar lebih matang sehingga siswa dapat belajar dan bekerja membuat surat secara berkelanjutan, maka teknik tersebut dipandang tepat diterapkan sebagai solusi permasalahan di atas. Berdasarkan latar belakang tersebut peneliti mengkaji melalui penelitian tindakan (action research) dengan judul "Penerapan Metode Task-Based Learning untuk Meningkatkan Keterampilan Menulis Surat Bisnis Berbahasa Inggris".

\section{METODE PENELITIAN}

Penelitian ini terdiri dari dua siklus, setiap siklus terdiri dari enam kali pertemuan. Penelitian ini terdiri dari dua jenis yaitu data kuantitatif dan data kualitatif. Data kuantitatif diwujudkan dengan hasil peniliaan keterampilan menulis surat bisnis berbahasa Inggris pada siswa kelas XII AP-1 SMK Pembangunan. Hasil penilaian keterampilan menulis surat diperoleh dari kegiatan evaluasi yang dilakukan setiap akhir pertemuan pada siklus I dan siklus II. Data kualitatif ini diperoleh dari hasil observasi dengan menggunakan lembar pengamatan aktivitas siswa, catatan lapangan serta data dokumentasi berupa foto dan video (Arikunto, 2016 : 95) selama pelaksanaan tindakan saat pembelajaran keterampilan menulis surat bisnis berbahasa Inggris melalui metode task-based learning. 
Model penelitian tindakan kelas yang akan digunakan dalam penelitian ini diadaptasi dari model Kemmis dan Mc. Taggart, yaitu model siklus yang dilakukan secara berulang-ulang dan berkelanjutan. Tiap siklus dilaksanakan sesuai dengan perubahan yang ingin dicapai, seperti yang telah didesain dalam siklus rancangan penelitian model spiral: Kemmis dan Mc Taggart. Adapun desain tindakan yang direncanakan dalam setiap siklusnya terdiri dari empat tahapan, yang dimulai dengan (1) perencana (planning), (2) pelaksanaan tindakan (acting), (3) observasi (observation), dan (4) refleksi (reflection).

\section{HASIL DAN PEMBAHASAN}

Pembahasan hasil penelitian ini akan dipaparkan secara jelas yakni mengenai hasil dari diterapkannya metode task-based learning pada pelajaran bahasa Inggris. Penelitian ini dilaksanakan dengan metode penelitian tindakan kelas, maka pemaparan ini akan dimulai dari pengambilan data awal yaitu siklus I hingga akhir tindakan yakni siklus II.

Rekapitulasi hasil peningkatan kegiatan guru, aktivitas siswa, dan hasil belajar disajikan dalam penjelasan berikut ini:

1. Keterampilan guru

Keterampilan guru dari siklus I sampai siklus II mengalami peningkatan terakhir mencapai skor 31 dengan kategori sangat baik. Peningkatan tersebut dapat ditunjukkan pada tabel berikut ini:

Tabel 2 Rekapitulasi Skor Keterampilan Guru Siklus I dan Siklus II

\begin{tabular}{clcc}
\hline No. & \multicolumn{1}{c}{ Indikator } & \multicolumn{2}{c}{ Skor } \\
& & Siklus I & Siklus II \\
\hline 1 & Melaksanakan kegiatan awal & 4 & 4 \\
2 & Membimbing pembentukan kelompok diskusi & 3 & 4 \\
3 & Menyampaikan materi pelajaran dengan media & 4 & 4 \\
$\quad$ power point & & \\
4 & Memberikan tugas untuk didiskusikan secara & 2 & 4 \\
$\quad$ kelompok & & \\
5 & Membimbing kelompok untuk mengerjakan & 3 & 4 \\
$\quad$ tugas & & 3 \\
6 & Membahas hasil diskusi kelompok & 3 & 4 \\
7 & Menyimpulkan pembelajaran & 3 & 4 \\
8 & Memberikan evaluasi & 24 & 31 \\
Jumlah skor & $75 \%$ & $97 \%$ \\
Persentase & Baik & Sangat Baik \\
Kriteria &
\end{tabular}

Berdasarkan hasil rekapitulasi keterampilan guru yang terlihat pada tabel 2, skor keterampilan guru pada siklus I dan siklus II secara umum sudah memenuhi indikator keberhasilan yang telah ditetapkan, yakni minimal baik. Selain itu hasil observasi juga menunjukkan bahwa keterampilan guru dalam mengajar pada siklus I memperoleh persentase $75 \%$ dan pada siklus II mengalami peningkatan menjadi $97 \%$. Keterampilan guru pada setiap indikator mengalami peningkatan sehingga pelajaran dapat dikatakan berhasil. Meliputi mengondisikan siswa untuk mengikuti pembelajaran guru perhatian siswa dengan menggunakan media audio visual.

Kegiatan membimbing pembentukan kelompok diskusi, menyampaikan materi pelajaran dengan tayangan media power point, memberikan tugas untuk 
didiskusikan secara kelompok, membimbing kelompok untuk mengerjakan tugas, membahas hasil diskusi kelompok, menyimpulkan pembelajaran dan memberikan evaluasi kelas, dan keterampilan mengajar kelompok kecil dan perorangan.

2. Aktivitas Siswa

Peningkatan aktivitas siswa dalam keterampilan menulis surat bisnis berbahasa Inggris melalui metode task-based learning dari siklus I dan siklus II dapat dilihat pada tabel 3 .

Tabel 3 Data Aktivitas Siswa Siklus I dan Siklus II

\begin{tabular}{clcc}
\hline No. & \multicolumn{1}{c}{ Aspek yang diamati } & \multicolumn{2}{c}{ Rata-rata Skor } \\
& \multicolumn{1}{c}{ Siklus I } & Siklus II \\
\hline 1 & $\begin{array}{l}\text { Perhatian siswa terhadap penjelasan guru } \\
2\end{array}$ & 2.6 & 4.4 \\
& $\begin{array}{l}\text { Keaktifan siswa dalam bertanya atau } \\
\text { menjawab pertanyaan yang diajukan guru }\end{array}$ & 2.33 & 4.03 \\
3 & $\begin{array}{l}\text { Keseriusan siswa dalam mengikuti bimbingan } \\
\text { yang diarahkan oleh guru }\end{array}$ & 2.67 & 4.07 \\
4 & $\begin{array}{l}\text { Respons positif siswa terhadap pelajaran } \\
\text { menulis surat bisnis bahasa Inggris }\end{array}$ & 2.73 & 3.93 \\
5 & $\begin{array}{l}\text { Siswa memperhatikan contoh surat bisnis } \\
\text { yang disajikan guru }\end{array}$ & 2.67 & 4.63 \\
6 & $\begin{array}{l}\text { Keaktifan siswa dalam merespons pendapat } \\
\text { anggota lain saat bekerja kelompok }\end{array}$ & 2.5 & 3.9 \\
7 & $\begin{array}{l}\text { Kesungguhan siswa dalam tes menulis surat } \\
\text { bisnis }\end{array}$ & 2.57 & 3.93 \\
8 & Sikap positif siswa dalam menulis surat bisnis \\
$\quad$ Jumlah & 2.6 & 4.13 \\
& $\quad \begin{array}{c}\text { Persentase } \\
\text { Katogori }\end{array}$ & 20.67 & 33.02 \\
& $\quad$ Cukup & $83 \%$ \\
Baik
\end{tabular}

Berdasarkan tabel 3 aktivitas siswa dalam keterampilan menulis surat bisnis berbahasa Inggris melalui metode task-based learning mengalami peningkatan terbukti pada perolehan jumlah rata-rata skor siklus I sebesar 20.67 dengan kategori cukup dan siklus II sebesar 33.02 dengan kategori baik. Hal ini berarti indikator pengamatan aktivitas siswa dari siklus I sampai siklus II mengalami peningkatan.

Aktivitas siswa pada tiap indikator mengalami peningkatan sehingga pembelajaran dapat dikatakan berhasil. Aktivitas siswa dalam perhatian siswa terhadap penjelasan guru menunjukkan bahwa sebagian besar siswa sudah fokus memperhatikan penjelasan guru. Aktivitas keaktifan siswa dalam bertanya atau menjawab pertanyaan yang diajukan guru atau siswa lain menunjukkan siswa sudah cukup aktif dalam bertanya atau pun menjawab pertanyaan yang diajukan oleh guru. Aktivitas keseriusan siswa dalam mengikuti bimbingan yang diarahkan oleh guru menunjukkan hampir seluruh siswa antusias memperhatikan tayangan pembelajaran dengan media power point. Aktivitas respons positif siswa terhadap pelajaran menulis surat bisnis berbahasa Inggris menunjukkan adanya pengaruh positif siswa terhadap kegiatan pembelajaran menulis surat bisnis berbahasa Inggris. Aktivitas siswa memperhatikan contoh surat bisnis berbahasa Inggris yang disajikan guru 
menunjukkan sebagian siswa memperhatikan contoh membuat surat bisnis berbahasa Inggris yang diberikan oleh guru. Dengan begitu siswa sedikit demi sedikit sudah dapat menulis surat bisnis berbahasa Inggris dengan aturan-aturan yang sudah disesuaikan. Aktivitas keaktifan siswa dalam merespons pendapat anggota lain saat bekerja kelompok menunjukkan siswa sudah mulai aktif berpartisipasi dalam mengerjakan tugas kelompok. Aktivitas kesungguhan siswa dalam tes menulis surat bisnis berbahasa Inggris menunjukkan sebagian besar siswa sudah mengerjakan tugas menulis surat bisnis berbahasa Inggris dengan mandiri karena guru berkeliling untuk memantau menghindari siswa mengerjakan tugas dengan menyontek antarteman. Aktivitas sikap positif siswa dalam menulis surat bisnis berbahasa Inggris menunjukkan siswa sudah mulai percaya diri mengerjakan tugas menulis surat bisnis berbahasa Inggris secara mandiri. Aktivitas siswa dalam pembelajaran membuktikan adanya motivasi dan keseriusan siswa dalam mengikuti pembelajaran di kelas yang nantinya akan berpengaruh terhadap hasil belajar siswa yang dapat meningkat.

3. Keterampilan Menulis Surat Bisnis Berbahasa Inggris

Peningkatan keterampilan menulis surat bisnis berbahasa Inggris mulai dari prasiklus, siklus I dan siklus II di tunjukkan pada tabel 4 berikut ini:

Tabel 4 Perbandingan Rata-Rata Nilai Tes Tiap Aspek Keterampilan Menulis Surat Bisnis Berbahasa Inggris

\begin{tabular}{clccc}
\hline No. & Aspek Penilaian & Prasiklus & Siklus I & Siklus II \\
& & & \\
\hline 1 & Kelengkapan bagian-bagian surat & 62 & 64.45 & 73.33 \\
2 & Ketepatan bagian surat & 62.67 & 81.11 & 87.11 \\
3 & Format surat & 68 & 79.33 & 85.56 \\
4 & Kesesuaian isi surat & 60 & 63.67 & 71.78 \\
5 & Penyusunan kalimat & 64.67 & 77.78 & 84.22 \\
6 & Ejaan dan tanda baca & 62.67 & 87.56 & 90.89 \\
& $\quad$ Jumlah & 385.68 & 448.23 & 492.89 \\
& Rata-rata & 64.17 & 73.27 & 80.28 \\
\hline
\end{tabular}

Hasil penelitian menunjuk- kan bahwa nilai rata-rata kemampuan siswa pada: (1) aspek kelengkapan bagian-bagian surat pada prasiklus memperoleh skor 62 mengalami peningkatan pada siklus I dengan skor 64,45 dan mengalami peningkatan kembali pada siklus II dengan skor 73,33; (2) aspek ketepatan bagian surat pada prasiklus memproleh skor 62.67 mengalami peningkatan pada siklus I dengan skor 81.11 dan mengalami peningkatan kembali pada siklus II dengan skor 87,11; (3) aspek format surat pada prasiklus memperoleh skor 68 mengalami peningkatan pada siklus I dengan skor 79.33 dan peningkatan pada siklus II dengan skor 85.56; (4) aspek kesesuaian isi surat pada prasiklus memperoleh skor 60 mengalami peningkatan di siklus I dengan skor 63.67 dan peningkatan kembali pada siklus II dengan skor 71.78; (5) aspek penyusunan kalimat pada prasiklus memperoleh skor 64.67 mengalami peningkatan pada siklus I dengan skor 77.87 dan peningkatan pada siklus II dengan skor 84.22 ; (6) aspek ejaan dan tanda baca pada prasiklus memperoleh skor 62.67 mengalami peningkatan pada siklus I dengan skor 87.56 dan peningkatan kembali pada siklus II dengan skor 90.89 . 


\section{Hasil Belajar}

Peningkatan hasil belajar siswa dalam keterampilan menulis surat bisnis berbahasa Inggris di tunjukkan pada tabel berikut ini:

Tabel 5 Rekapitulasi Hasil Belajar Prasiklus, Siklus I, dan Siklus II

\begin{tabular}{clccc}
\hline No. & \multicolumn{1}{c}{ Pencapaian } & Prasiklus & Siklus I & Siklus II \\
\hline 1 & Nilai Terendah & 56 & 64.33 & 72 \\
2 & Nilai Tertinggi & 83 & 80.67 & 93.33 \\
3 & Nilai Rata-rata & 64.17 & 73.39 & 81.12 \\
4 & Jumlah siswa Tuntas & 7 & 18 & 27 \\
5 & Jumlah siswa Tidak Tuntas & 23 & 12 & 3 \\
6 & Persentase Ketuntasan & $23 \%$ & $60 \%$ & $90 \%$ \\
7 & Persentase Ketidaktuntasan & $77 \%$ & $40 \%$ & $10 \%$ \\
\hline
\end{tabular}

Data pada tabel 5 menunjukkan bahwa perolehan hasil belajar ranah kognitif pada siklus I belum memenuhi indikator keberhasilan yang ditetapkan. Namun, pada siklus II sudah memenuhi indikator keberhasilan yaitu ketuntasan klasikal minimal $85 \%$ terpenuhi. Selain itu dapat dilihat bahwa terjadi peningkatan presentasi hasil belajar kognitif yang naik pada siklus II. Pada siklus I memperoleh persentase $60 \%$ anak yang sudah mencapai KKM yaitu 75. Dan pada siklus II mendapat peningkatan persentase $90 \%$ anak yang sudah mencapai KKM.

Task-Based Language Teacher (TBLT) dalam pembelajaran menulis surat niaga berbahasa Inggris menunjukkan bahwa jumlah partisipasi aktif mahasiswa meningkat seiring ditemukannya fakta bahwa mereka mulai intens mengangkat tangan dalam diskusi; melakukan komunikasi dalam pengerjaan task/tugas; mengumpulkan tugas tepat waktu. Amrullah (2015: 129-141) berjudul "Belajar Berbicara Bahasa Inggris Melalui Pendekatan Pembelajaran Berbasis Tugas" menunjukkan bahwa terdapat peningkatan yang signifikan pada kemampuan berbicara bahasa Inggris mahasiswa setelah mengikuti pembelajaran mata kuliah speaking II melalui pendekatan pembelajaran berbasis tugas. Sari dkk. (2018: 104-115) berjudul "Peningkatan Menulis Karya Ilmiah Berbahasa Inggris dengan Metode Task-Based Language Teaching Prodi Pendidikan Bahasa Inggris menunjukkan bahwa metode TBLT terbukti meningkatkan aktivitas belajar mahasiswa, interaksi dalam pembelajaran, dan kemandirian mahasiswa: peningkatan rerata kemampuan mahasiswa dalam menulis karya ilmiah: proses belajar mengajar penulisan karya ilmiah lebih berbobot, menarik, dan menyenangkan. Berdasarkan penelitian yang telah dilakukan di SMK Pembangunan terlihat bahwa terjadi peningkatan keterampilan guru, aktivitas siswa dan hasil belajar pada pelajaran bahasa Inggris di kelas XII.

Pada peningkatan keterampilan guru di dukung dengan keterampilanketerampilan dasar mengajar yang diterapkan selama proses pembelajaran. Adapun 8 keterampilan dasar mengajar (Anitah, 2014:7.1-8.3), yaitu keterampilan membuka dan menutup pelajaran, keterampilan bertanya, keterampilan memberi penguatan, keterampilan mengadakan variasi, keterampilan menjelaskan, keterampilan membimbing diskusi kelompok kecil, keterampilan mengelola. Berdasarkan hasil rekapitulasi keterampilan guru dimana, skor keterampilan guru pada siklus I dan siklus II secara umum sudah memenuhi indikator keberhasilan yang telah ditetapkan, yakni minimal 
baik. Selain itu, hasil observasi juga menunjukkan bahwa keterampilan guru dalam mengajar pada siklus I memperoleh persentase $75 \%$ dan pada siklus II mengalami peningkatan menjadi $97 \%$. Keterampilan guru pada setiap indikator mengalami peningkatan sehingga pelajaran dapat dikatakan berhasil.

Pada aktivitas siswa dalam keterampilan menulis surat bisnis berbahasa Inggris melalui metode task-based learning mengalami peningkatan terbukti pada perolehan jumlah rata-rata skor siklus I sebesar 20.67 dengan kategori cukup dan siklus II sebesar 33.02 dengan kategori baik. Hal ini berarti indikator pengamatan aktivitas siswa dari siklus I sampai siklus II mengalami peningkatan. Aktivitas siswa pada tiap indikator mengalami peningkatan sehingga pembelajaran dapat dikatakan berhasil.

Pada keterampilan menulis surat bisnis berbahasa Inggris memperoleh nilai ratarata yang tiap siklusnya mengalami peningkatan. Pada Prasiklus nilai rata-rata keterampilan menulis siswa diperoleh nilai 385.68 dengan rata-rata 64.17 dengan kategori cukup, kemudian pada Siklus I nilai yang diperoleh 448.23 dengan rata-rata 73.27 dengan kategori baik dan pada Siklus II nilai yang diperoleh 492.89 dengan rata-rata 80.28 dengan kategori baik. Dengan meningkatnya keterampilan guru, aktivitas siswa dan kemampuan menulis siswa membuktikan bahwa penerapan metode task-based learning dalam keterampilan menulis surat bisnis berbahasa Inggris merupakan salah satu upaya yang efektif untuk meningkatkan kualitas pelajaran bahasa Inggris di Sekolah Menengah Kejuruan.

Dengan demikian, dapat dijelaskan bahwa penerapan metode task-based learning dalam keterampilan menulis surat bisnis berbahasa Inggris pada siswa kelas XII AP1 SMK Pembangunan Jakarta dapat membawa dampak yang positif bagi hasil belajar jika dilaksanakan dan diterapkan dengan baik. Metode task-based learning adalah metode pengajaran bahasa yang menggunakan tugas-tugas dalam pengajaran bahasa agar pengajaran bahasa lebih komunikatif. Karena metode task-based learning adalah model yang menuntut siswa agar bertanggung jawab terhadap tugas yang di terima dikarenakan siswa akan menjelaskan tugas yang menjadi tanggung jawabnya pada teman satu kelompok. Melalui metode task-based learning dapat meningkatkan siswa secara aktif dalam proses pembelajaran. Hal itu berakibat pada pengetahuan yang didapatkan siswa menjadi lebih bermakna dan berdampak pada meningkatnya hasil belajar siswa.

\section{SIMPULAN}

Berdasarkan hasil pembahasan, disimpulkan bahwa melalui penerapan metode taskbased learning dalam meningkatkan keterampilan menulis surat bisnis berbahasa Inggris pada siswa kelas XII AP1 SMK Pembangunan Jakarta dapat memecahkan masalah pelajaran bahasa Inggris. Peningkatan kualitas pembelajaran bahasa Inggris tersebut ditunjukkan dengan meningkatnya kegiatan guru, aktivitas siswa, dan hasil belajar siswa

\section{DAFTAR PUSTAKA}

Ali, M., Emzir, E., \& Rafli, Z. (2017). The Effect of learning problem based learning (PBL) and task based learning (TBL) learning models and learning style to skill writing narration. Ijlecr-International Journal of Language Education and Culture Review, 3(2), 112-121. https://doi.org/10.21009/IJLECR.032.010

Amrullah, A. (2015). Belajar berbicara bahasa inggris melalui pendekatan pembelajaran berbasis tugas (Penelitian tindakan di FKIP Universitas Mataram). BAHTERA: 
$\begin{array}{lllll}\text { Jurnal Pendidikan Bahasa Dan } & \text { Sastra, }\end{array}$ https://doi.org/10.21009/BAHTERA.142.03

Anitah, S. W., Hermawan., Herry, A., \& Ruhiat, T. (2014). Strategi pembelajaran di SD. Tanggerang Selatan: Universitas Terbuka.

Fitri, R. (2016). Penerapan teknik pemodelan untuk meningkatkan kemampuan menulis surat resmi siswa Kelas VIII SMP. Jurnal Gramatika, 2(2), 80245. Diakses dari http://ejournal.stkip-pgri-sumbar.ac.id/index.php/jurnalgramatika/article/view/1200

Istiara, F., \& Lustyantie, N. (2017). TheInfluence of cooperatif learning model and critical thinking on essay writung skills (Experiment study). Word Journal of English Language, 7(2), 22-30. https://doi.org/10.5430/wjel.v7n2p22

Artamiati, N. L. P. S., Efendi, E., \& Gagaramusu, Y. (2017). Meningkatkan keterampilan siswa menulis surat dinas melalui metode pemberian tugas di Kelas V SD Inpres 12 Bajawali. Jurnal Kreatif Online, 7(4). http://jurnal.untad.ac.id/jurnal/index.php/JKTO/article/view/3882

Nurjanna, N. (2015). Penggunaan Metode Pemberian Tugas Untuk Meningkatkan Keterampilan Menulis Surat Siswa Kelas IV SDN 2 Lais. Jurnal Kreatif Tadulako, 4(8), $117862 . \quad$ Diakses dari https://media.neliti.com/media/publications/117862-ID-penggunaan-metodepemberian-tugas-untuk.pdf

Pujiastuti, R. R. (2016). Efektifitas penggunaan model pembelajaran kooperatif dengan presentasi untuk meningkatkan kemampuan belajar menulis surat kelas XI PM di SMK Negeri 48. Jurnal Ilmiah Econosains, 14(2), 55-61. http://doi.org/10.21009/econosains.014.2.6

Sari, D. S., Asman, H., \& Rodhi, R. (2018). Peningkatan menulis karya ilmiah berbahasa Inggris dengan metode task based language teaching Prodi Pendidikan Bahasa Inggris. Edukasi: Jurnal Pendidikan, 16(1), 104-115. Diakses dari http://www.journal.ikippgriptk.ac.id/index.php/edukasi/article/view/841/740

Tarigan, H. G. (2008). Menulis sebagai suatu keterampilan berbahasa (Edisi Revisi). Bandung: angkasa.

Ulfa, R. N. (2018). Pelatihan guru SMK Muhammadiyah 4 Slipi Jakarta mengenai business letter berbahasa Inggris. Jurnal Pengabdian dan Kewirausahaan, 2(1), 61-67. Diakses dari https://journal.ubm.ac.id/index.php/pengabdian-dankewirausahaan/article/view/1134/995 